\title{
Corneal Remodeling to Correct Presbyopia: Mechanism of A Shape-Changing Corneal Inlay
}

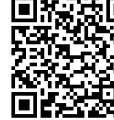

\author{
Enrique Barragan-Garza ${ }^{1}$, Luis Vargas ${ }^{2}$ and Briana Lee ${ }^{2}$ \\ ${ }^{1}$ Laser Ocular Hidalgo, Mexico
}

${ }^{2}$ ReVision Optics Inc, USA

Submission: December 21, 2017; Published: January 08, 2018

*Corresponding author : Enrique Barragan-Garza, Hidalgo 2040 PB Cons. 9, Col. Obispado, Monterrey, NL, 64060, Mexico, Tel: 52-1-8181616311; Email: enrique_barragan2000@yahoo.com

Keywords : Corneal Remodeling; Epithelial Remodeling; Corneal Inlay; Raindrop; LASIK; Presbyopia

\section{Introduction}

Presbyopia is the inability to focus on near objects which physiologically manifests around 40 years of age due to reduction in elasticity of the crystalline lens causing a reduction in accommodation [1]. Surgical treatment options include LASIK monovision, multifocal LASIK, accommodative, multifocal, or extended depth of focus intraocular lenses (IOLs), and scleral expansion techniques. Recently, technological advances have led to corneal inlays as an alternate surgical treatment option to correct presbyopia. Because the inlay procedures are additive and do not require removal of corneal tissue, these devices can be removed and often times baseline acuity levels recovered with no additional surgery [2]. The Raindrop Inlay increases the curvature of the cornea to improve near vision. This shapechanging mechanism involves intricate biomechanical changes to two different layers of the corneal tissue, which ultimately reduces visual symptoms compared to other presbyopia correcting optical systems such as Multifocal IOLs [3].

The Raindrop Inlay is $2 \mathrm{~mm}$ in diameter, $\sim 34 \mu \mathrm{m}$ thick at the center, and made up of a hydrogel material that has a similar index of refraction to that of the cornea, and has no intrinsic power. It is placed under an $8 \mathrm{~mm}$-diameter femto second flap at 30\% central corneal thickness in the non-dominant eye [4-6]. Near and intermediate vision is improved by changing the shape of the cornea to induce a continuous center-near power profile [3]. In the US FDA Pivotal Study, on average in the inlay eye, patients gained 5 lines of near vision, 2.5 lines of intermediate vision, and little change to binocular distance vision [7].

The corneal structural changes that occur after Raindrop Inlay implantation was deduced in a study by utilization of anterior segment optical coherence tomography (AS-OCT) to measure changes in anterior stromal elevation and epithelial thickness (Figure 1, top) and wavefront measurements to measure the change in total anterior corneal surface (Figure 1, bottom right) [4]. The inlay's volume raises the anterior stroma which is demonstrated by a change to the shape of Bowman's layer. The anterior stromal thickness change above the inlay was shown to be $\sim 28 \mu \mathrm{m}$ on average (Table 1 ), which is only $\sim 85 \%$ of the inlay's central thickness (Figure 1). The $28 \mu \mathrm{m}$ rise in the anterior stroma lifts the overlying epithelium, resulting in central epithelium thinning by $\sim 18 \mu \mathrm{m}$ (Table 1 ). This epithelial thinning tapers out peripheral to the inlay diameter, leading to slight peripheral thickening, not measurable by AS-OCT. The resulting anterior elevation change to the central cornea was $\sim 10 \mu \mathrm{m}$ (the difference in $28 \mu \mathrm{m}$ anterior stroma thickness change and $18 \mu \mathrm{m}$ epithelial thinning) (Figure 1, Table 1), which gradually reduces to zero as the epithelium redistributes to about twice the inlay diameter. This steady change in corneal surface height creates the inlay-induced central steepening power profile resulting in $4.3 \mathrm{D}$ add power induced at the center $[3,4]$.

Table 1: Numeric values of stromal, epithelial, and total anterior mean changes with standard deviations (SD).

\begin{tabular}{|c|c|c|}
\hline & Mean $(\mu \mathrm{m})$ & $\mathbf{S D}(\mu \mathrm{m})$ \\
\hline Anterior Stroma Change & 28.2 & 8.3 \\
\hline Epithelial Thickness Change & -18.4 & 7.1 \\
\hline Total Anterior Corneal Surface Change & 9.8 & 3.4 \\
\hline
\end{tabular}



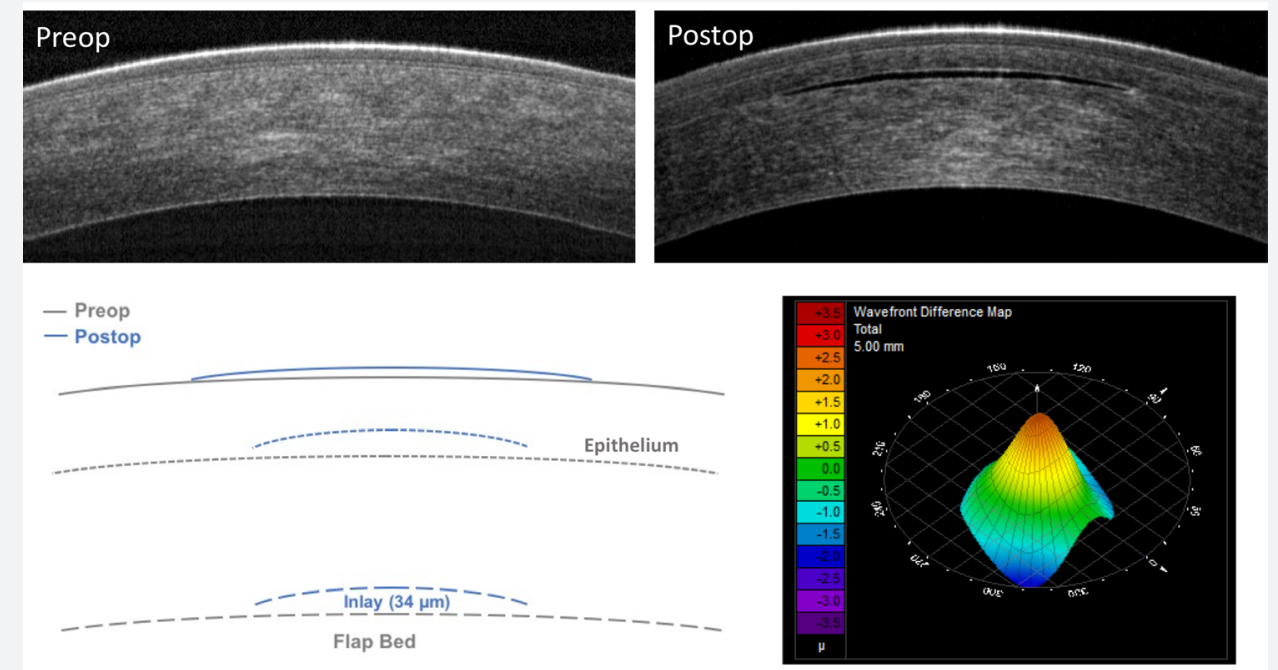

RVO-767 Rev 1

Figure 1: Examples of preop and postop AS-OCT images (Top). Schematic representation of the corneal changes after inlay implantation. Postop-Preopwavefront difference map (iTrace).

Epithelial remodeling has also been demonstrated with hyperopic and myopic LASIK. In myopic LASIK the epithelium thickens across the central ablation zone [8], whereas hyperopic LASIK the epithelium thins at the center and thickens at the midperipheral zone where ablation is greatest [9]. Until recently, the mechanism of remodeling that happens to the stroma and epithelium when an inlay is implanted concomitantly with LASIK was unknown. Interestingly, the epithelial thickness profile was nearly identical and the thinning of the epithelium was not a function of the amount of hyperopic or myopic treatment. This translated into similar add power profiles derived from the wavefront measurements, with the hyperopic group having slightly more induced add power profile, especially at the central $0.9 \mathrm{~mm}$ zone. Thus, the clinical outcomes were the same between the LASIK groups, with differences less than 2 Snellen letters between the two groups. A limitation of this study is that the average SE ablation was $+1.71 \mathrm{D}$ for hyperopic treatment and $-2.48 \mathrm{D}$ for myopic treatment [10]. Whether or not this remodeling effect is consistent with higher levels of treatment has yet to be elucidated.

Interestingly, the preoperative epithelial thickness and total corneal thickness does not correlate with the final central anterior surface height change. Additionally, the central epithelial thickness change was not a function of preop corneal thickness nor final anterior surface change at the center [4]. This suggests that there is a buffer to the level of corneal/epithelial remodeling that may result. One suggestion by the authors is that the superficial epithelial cells may be more dynamic in response to external forces, thus they tend to flow outward in response to regions of greater epithelial thickness curvature until the resistance of lower cells ultimately stops this flow [4]. Regardless of whether or not this theory is accurate, the tear film plays a crucial role in maintenance, hydration, and fluidity of the cornea $[11,12]$, and will be pertinent to these structural alterations to the anterior cornea taking place. Future studies focused on ocular surface therapy both pre- and post-inlay implantation will be useful to determine if maintenance of the ocular surface is correlated with positive outcomes.

\section{Conflict of Interest}
a. Consultant for ReVision Optics, Inc.
b. Employee of ReVision Optics, Inc.

\section{References}

1. Moussa K, Jehangir N, Mannis T, Wong WL, Moshirfar M (2017) Corneal Refractive Procedures for the Treatment of Presbyopia. Open Ophthalmol J 11: 59-75.

2. Arlt E, Krall E, Moussa S, Grabner G, Dexl A (2015) Implantable inlay devices for presbyopia: the evidence to date. Clin Ophthalmol 9: 129137.

3. Steinert RF, Schwiegerling J, Lang A, Roy A, Holliday K, et al (2015) Range of refractive independence and mechanism of action of a corneal shape-changing hydrogel inlay: results and theory. J Cataract Refract Surg 41(8): 1568-1579.

4. Lang AJ, Holliday K, Chayet A, Barragán-Garza E, Kathuria N (2016) Structural Changes Induced by a Corneal Shape-Changing Inlay, Deduced From Optical Coherence Tomography and Wavefront Measurements. Invest Ophthalmol Vis Sci 57(9): OCT154-OCT161.

5. Pinsky PM (2014) Three-Dimensional Modeling of Metabolic Species Transport in the Cornea with a Hydrogel Intrastromal Inlay. Invest Ophthalmol Vis Sci. 
6. Whitman J, Dougherty PJ, Parkhurst GD, Olkowski J, Slade SG, et al (2016) Treatment of Presbyopia in Emmetropes Using a ShapeChanging Corneal Inlay: One-Year Clinical Outcomes. Ophthalmology 123(3): 466-475.

7. ReVision Optics I.. Raindrop Near Vision Inlay Professional Use Information.

8. Reinstein DZ, Archer TJ, Gobbe M (2012) Change in epithelial thickness profile 24 hours and longitudinally for 1 year after myopic LASIK three-dimensional display with Artemis very high-frequency digital ultrasound. J Refract Surg 28(3): 195-201.

9. Reinstein DZ, Archer TJ, Gobbe M, Silverman RH, Coleman DJ (2010) Epithelial thickness after hyperopic LASIK: three-dimensional display with Artemis very high-frequency digital ultrasound. J Refract Surg 26(8): 555-564.

10. Steinert RF, Koch DD, Cochener B, Lang A, Barragán-Garza E, et al (2017) Corneal remodeling after implantation of a shape-changing inlay concurrent with myopic or hyperopic laser in situ keratomileusis. J Cataract Refract Surg 43(11): 1443-1449.

11. Bron AJ, Tiffany JM, Gouveia SM, Yokoi N, Voon LW (2004) Functional aspects of the tear film lipid layer. Exp Eye Res 78(3): 347-360.

12. Bron AJ, de Paiva CS, Chauhan SK, Bonini S, Gabison EE, et al. (2017) TFOS DEWS II pathophysiology report. Ocul Surf 15(3): 438-510.

\section{Your next submission with Juniper Publishers will reach you the below assets}

- Quality Editorial service

- Swift Peer Review

- Reprints availability

- E-prints Service

- Manuscript Podcast for convenient understanding

- Global attainment for your research

- Manuscript accessibility in different formats

( Pdf, E-pub, Full Text, Audio)

- Unceasing customer service

Track the below URL for one-step submission https://juniperpublishers.com/online-submission.php 